\title{
The Effectiveness of Sharing Blended Project Based Learning (SBPBL) Model Implementation in Operating System Course
}

\author{
https://doi.org/10.3991/ijet.v15i05.11266 \\ Wahyudi Wahyudi \\ STMIK Indonesia Padang, Padang, Indonesia \\ wahyudi@stmikindonesia.ac.id
}

\begin{abstract}
The implementation of e-learning models in higher education have been tested widely, in order to discover their flexibility in research to time, place, students, courses, and other diverse conditions. This paper resulted from testing the implementation of an SBPBL model. This model maximizes shared e-learning resources in project based blended learning. This research used quantitative research design, with Research and Development using the ADDIE model in an Operating System course. Data were collected by questionnaires, interviews, and observation, then analyzed descriptively. Validity, practicality and effectives of the model were confirmed. Therefore, it is suitable to apply this blended learning system in such course.
\end{abstract}

Keywords - Sharing, project based learning, blended learning, SBPBL, motivation.

\section{Introduction}

E-learning has been and will be an important part of higher education in Indonesia. This is a national priority program to improve quality education in Industrial Revolution 4.0 [1]. E-learning systems have a wide range of uses, across space, time, and socio-economic group, for anyone, anywhere, anytime. This is a solution to education problems, related to educational equity, expanding access to quality education for all levels of society [2]. E-learning is an alternative to help people get access to education. However e-learning development needs some resources: a) computer hardware, b) computer software, c) internet device, d) human resources, and e) content development center [3].

The main determinant of e-learning success by students is information technology infrastructure, and organizational support. Higher education institution wanting to implement e-learning in a quality manner for students must build and maintain the capacity adequately. The teaching staff is asked to support and be involved e-learning [4].

Blended Learning (BL) is a new development in education, combining face-to-face classes with e-learning, which allows for the benefits of both teaching methods [5]. 
Other advantages include greater flexibility [6] and reduced costs compared to traditional classes, especially when large numbers of students are taught. BL equips traditional classes with online materials: a) has a positive effect on student performance [7], b) allows the promotion of a flexible learning environment and strengthens student autonomy, reflection, and motivation [8], c) facilitates review and control learning [9].

There are several ways to implement active learning. One of them is Project Based Learning (PBL) which has been gaining ground and is being successfully applied in several fields [10]. It consists of a project based methodology where students must independently solve technical problems similar to those faced in their professional lives [11]. However, difficulties found in PBL are a measurement of how knowledge is generated and disseminated, and how students are still lacking teamwork skill in the learning process [12].

Sharing (S) is a concept of shared use of resources, aimed at obtaining higher cost reduction and flexibility. Using shared workspaces improves collaborative project learning [13]. Students sharing technology affects the classroom environment and what students learn [14].

To the implementation of the SBPBL model consists of five parts: a) Sharing computer hardware; b) Sharing e-learning software; c) Sharing internet device; d) Project Based Learning (PBL) model; e) Blended Learning (BL) model.

\section{Overview of SBPBL}

$\mathrm{S}$ is shared use of resources:

- Sharing computer hardware

- Sharing e-learning software

- Sharing internet devices; in the Personal Learning Network (PLN) (illustrated in Fig. 1).

Computer hardware can consist of personal computers, laptops, and smartphones. Internet devices can consist of modems, and internet storage devices. E-learning software includes activities:

- Course design by lecturer

- Classroom Learning activities: teaching by the lecturer, classroom interaction by the student, group activities by student

- Access by any device, anywhere by a parent, student, and lecturer

- Used in personal learning: anytime, anywhere

- Online materials: YouTube, e-journal, e-book.

BPBL consists of PBL and BL. PBL focuses on creative thinking, problem solving, and student interaction. Projects are complex tasks based on challenging questions from real-world problems. Students have a relatively long time working on group 
projects, and each student presents results. This paperless system concept maximizes the shared use of e-learning resources that students have in a group.

Since 1994, higher education has been able to maximize shared e-learning resources. The SBPBL utilizes the e-learning resources of universities, lecturers, and students. Students have computer hardware resources, which they can share. As a group they can rent computers at Internet cafes. Alternatively, each group can own at least one laptop device. In this research, $66 \%$ of students did not have laptops. Implementation of sharing computer hardware really helped students who did not have a laptop.

Computer networking hardware resources for students and lecturers cold be smartphones [15] as modems. To access the internet. In addition photos and videos could be accessed using a smartphone camera. Or server computers, workstation computers, internet access devices, and other network hardware could be the responsibility of the higher education institution.

One e-learning software resource uses LMS Edmodo. Higher education can use it for lecturers, and students for free. Edmodo design is standard, and cannot be modified. Edmodo menu interactivity is linear interactive. Menus are made LIFO (Last In, First Out). E-learning material that has been created can be edited for next semester. Higher education does not need to buy e-learning software. E-learning video software uses by YouTube [16]. The researcher's, especially Operating Systems course using e-learning software products can be accessed for free by any university, lecturer and student.

The effectiveness of e-learning models is influenced by student characteristics such as learning styles, learning motivation, learning behaviors and prior knowledge [17]. In this study, the effectiveness of the e-learning model was measured by the level of student learning motivation. Motivation is the reason for human actions, desires, and needs [18]. A person is not motivated by other individuals but from within him or herself. Learning motivation is identified as the most important factor in individual achievement in learning tasks. Intelligence is not enough, motivation is actually essential in order for goals to be achieved [19].

An operating system manages all the resources on a computer system, and support services [20]. It is the main interface between system hardware, and user applications [21]. It works with computers, manages resources, and uses them optimally. This is why the Operating System course is important [22]. Graduate of this course can fix software and hardware problems. 


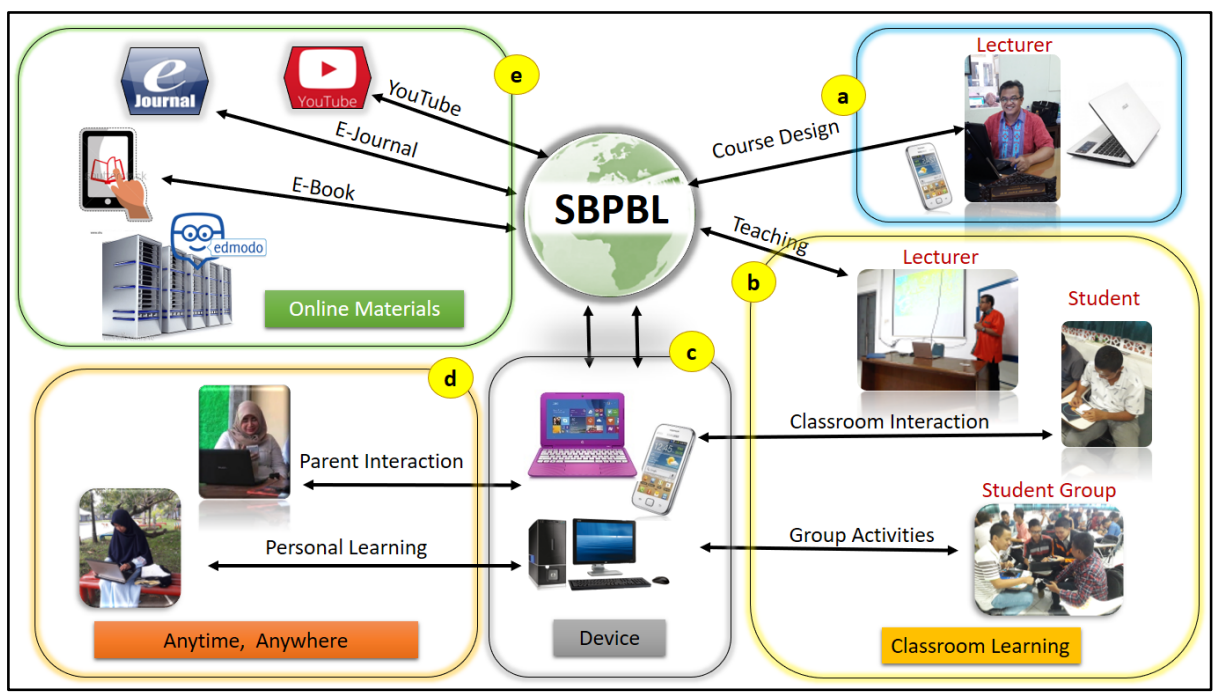

Fig. 1. SBPBL (Sharing Blended Project Based Learning)

This study aims to determine the impact of implementation of SBPBL model as a problem solving limited e-learning resource in higher education, to increase student motivation in Operating System course.

\section{$3 \quad$ Method}

\subsection{Participants and the learning context}

The research uses quantitative research design, with Research and Development ADDIE model. The object of the research was 4S1E, and 4S1C group students, Operating System courses, 4th semester at STMIK Indonesia Padang. The students in these two groups did not have a statistically significant difference $(\mathrm{P}<0.005)$ in terms of age, gender, and learning ability. The 4S1E group was the experimental class, and the 4S1C group was the control class.

Operating System course is a compulsory subject at STMIK Indonesia Padang. Learning is done 16 times with $62 \%$ face to face, and $38 \%$ online. This course was the learning context in this research.

\subsection{Validity data}

Validity data was obtained from the results of the validation of learning plans, learning units, website e-learning, SBPBL model e-book, and e-book of Operating System courses. Data validity was in the form of quantitative, and qualitative data. Quantitative data were obtained from validation questionnaires. Qualitative data was written input from validation questionnaires, and results of consultation with the 
validators. These were six experts: two learning technologies expert, one educational technology expert, one language expert, and two computer experts. These six expert panel members judged the extent to which the items in the course represented the constructs measured.

\subsection{Practicality data}

The practicality data was quantitative. This was obtained from the results of observation sheets by five observers, and results of questionnaire entries from students and lecturers. Other data was obtained from the analysis of the implementation of Website, E-Book, and E-Book model courses. Lecturers and institutional leaders were interviewed regarding e-learning facilities and current blended learning systems.

\subsection{Effectiveness data}

The effectiveness data of the SBPBL model was measured by the level of student learning motivation. This was obtained from observation sheets by five observers, and results of questionnaire entries from students.

\subsection{Instruments}

In product development models some instruments are used to test the validity of ebook models, learning units, websites, and e-books for Operating System courses. In this research the aspects tested were: substance, technical, and language. Validation used a Likert scale.

Research questionnaire answers were analyzed using Cronbach's Alpha which measures reliability of indicators. Cronbach's Alpha was used to detect inconsistent indicators. Aiken's V formula was used to calculate content validity coefficients.

Practicality testing was done to measure the practicality of the implementation of the learning model. This testing included a practicality test of the implementation model, the learning unit, the website, and the e-book learning material. The instrument;

- Model practicality assessment sheets

- Website practicality assessment sheets

- E-book Operating System courses practicality assessment sheets

The model practicality and the website practicality assessment sheet instrument measured the practicality of a model SBPBL used a Likert scale. The assessment indicators were attractiveness, development process, convenience, functioning, and reliability.

The practicality assessment sheet instrument for the e-book Operating System courses measured its practicality for students. These assessment sheets also used a Likert scale. The indicators were learning objectives, learning stages (syntax), 
learning materials, learning strategies and methods, time allocation, technical aspects, and language aspects.

The effectiveness test determined the impact of a model to produce results in accordance with expectations. The effectiveness of the learning process was measured by the motivation level of the students in Operating System courses. The indicators were perseverance in learning, tenacity in doing assignments, preference for group work, interest in various problems, interest in solving problems, boredom with assignments, and satisfaction with the learning process.

\section{$4 \quad$ Results}

All the expert validated instruments used Aiken's V validity coefficient. Thus, the data can be considered valid. The practicality of the model was assessed on five aspects using seventeen statements and a Likert scale. Practicality testing of the SBPBL model was in the form of a Focus Group Discussion (FGD) by six experts, which showed that the model was very practical, with an average score of 3.45. Lecturers considered the model very practical, with an average score of 3.35. Students considered the model very practical, with an average score of 3.25 (see Fig. 2).

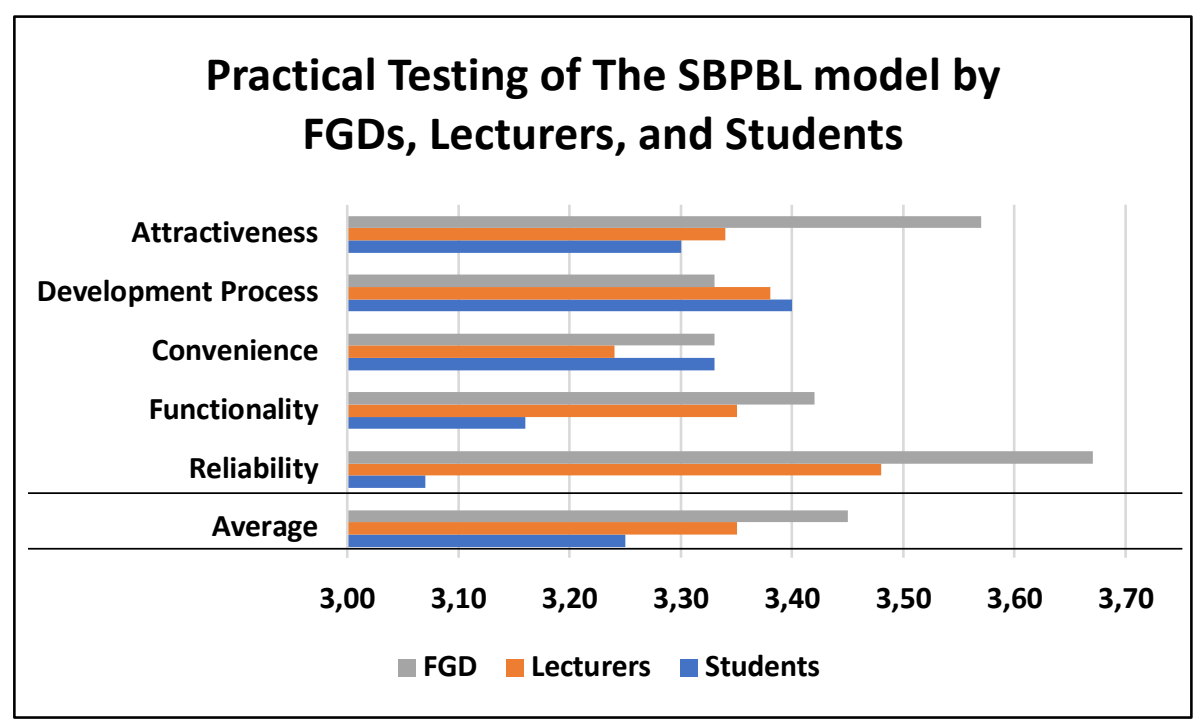

Fig. 2. Practical Testing of The SBPBL model by FGDs, Lecturers, and Students

The practicality of the website was assessed on five aspects using twenty-seven statements and a Likert scale. Practicality testing of the website was the form of an FGD by six experts, which showed that the website is considered very practical, with an average score of 3.38. Lecturers considered the website very practical, with an average score of 3.31. Students considered the website practical, with an average score of 3.17 (see Fig. 3). 


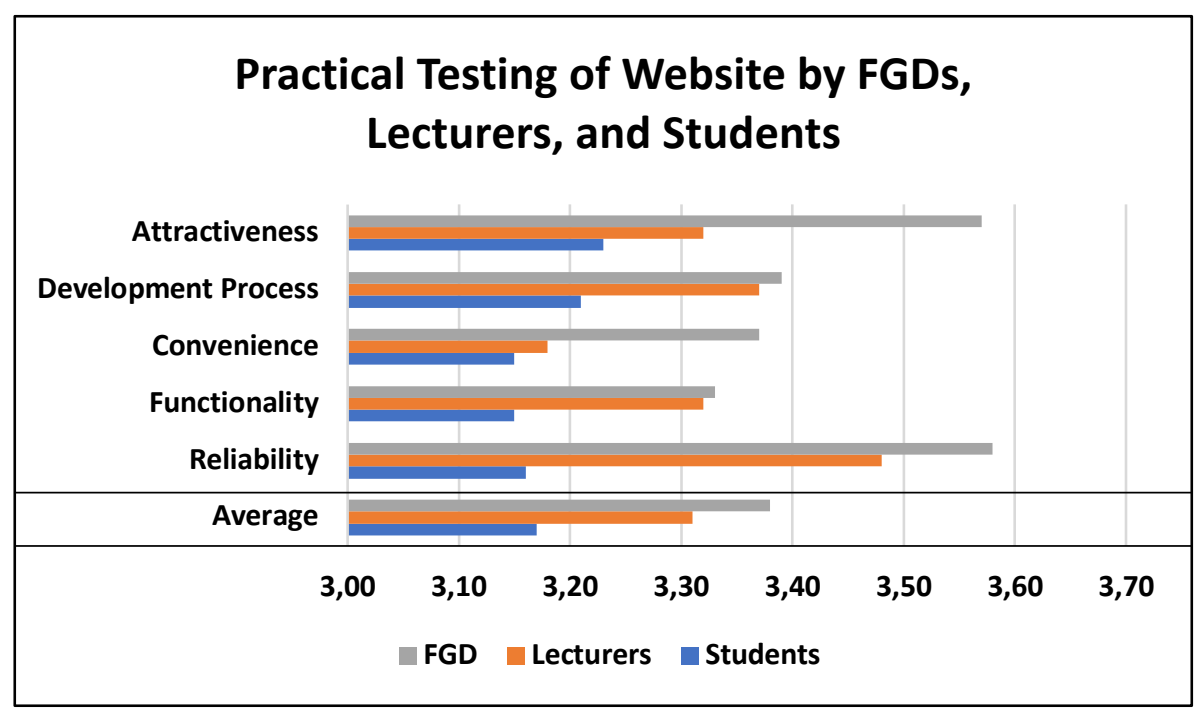

Fig. 3. Practical Testing of The Website by FGDs, Lecturers, and Students

The practicality of the e-book was assessed on three aspects using eight statements and a Likert scale. Practicality testing of the e-book was in the form an FGD by six experts, which showed that the e-book was very practical, with an average score of 3.47. Lecturers considered the e-book very practical, with an average score of 3.41. Students considered the e-book practical, with an average score of 3.17 (see Fig. 4).

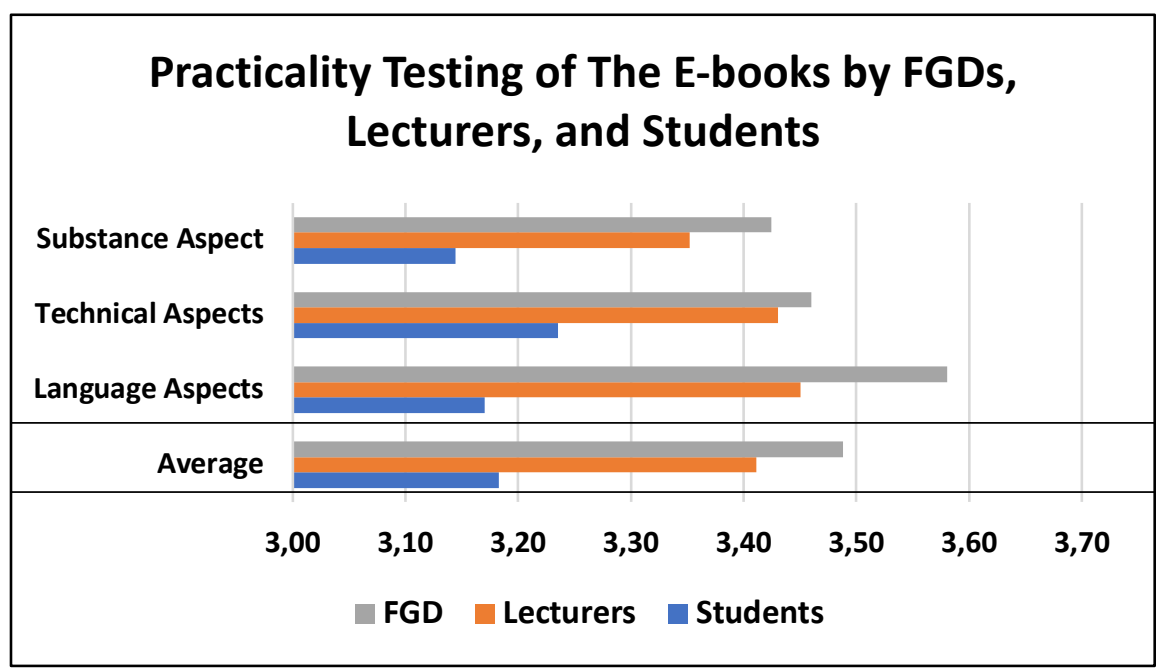

Fig. 4. Practicality Testing of The E-Books by FGDs, Lecturers, and Students 
Effectiveness of the SBPBL model was tested regarding student learning motivation. The control class reached high criteria, with an average score of 2.98. The experimental class reached very high criteria, with an average score of 3.26 (Fig. 5).

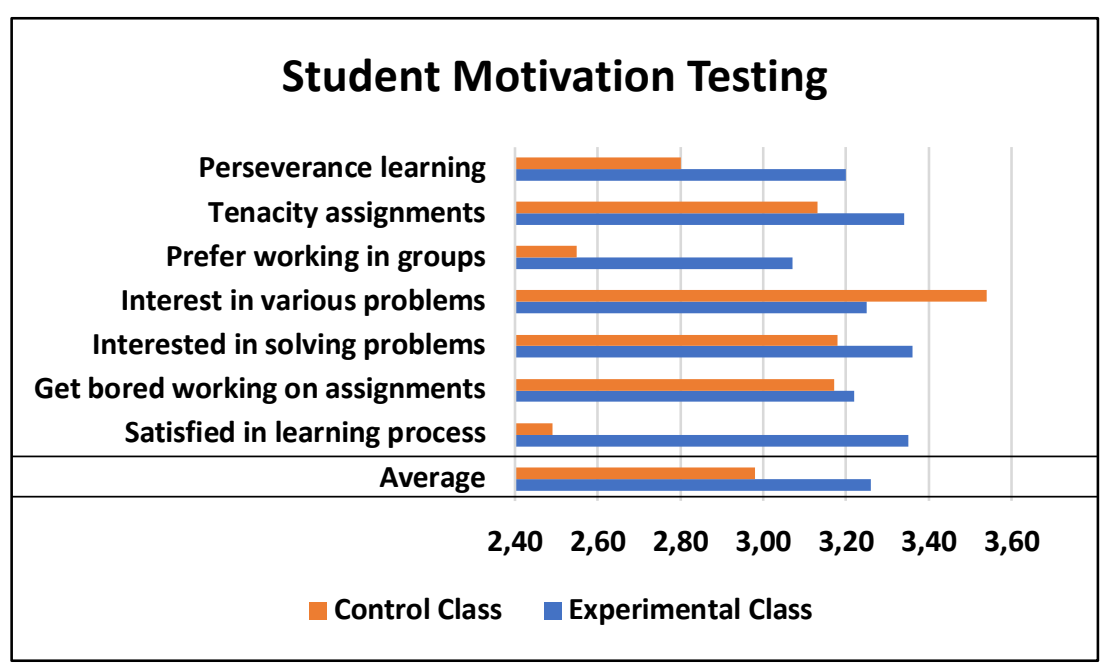

Fig. 5. Student Motivation Testing

\section{Conclusion}

The results of the implementation of the SBPBL model in Operating System course is that it has maximized the use of e-learning resources of institutions, lecturers, and students:

- The model has been evaluated to be very practical by FGD, lecturers, and students

- The e-book teaching materials have been evaluated to be very practical by FGD and lecturers and practical by students

- E-learning website has been tested very practically by FGDs, and lecturers, as well as practically by students

- Student learning motivation improved with very high criteria. Therefore, it is feasible to apply a blended learning system in other subjects.

\section{Acknowledgement}

Thank you very much to chairman of Yayasan Amal Bakti Mukmin Padang, and STMIK Indonesia Padang, who have contributed to completion this research. Contract number: 037/K.A/LPPM/STMIK-I/2018. 


\section{$7 \quad$ References}

[1] Kemenristekdikti, Menristekdikti _ Kebijakan Pendidikan Tinggi Harus Relevan dengan Revolusi Industri 4. Jakarta: KEMĒNRISTEKDIKTI, 2018.

[2] T. Blayone, R. VanOostveen, W. Barber, M. DiGiuseppe, and E. Childs, "Democratizing digital learning: Theorizing the Fully Online Learning Community model," To Be Submitt., vol. 14, no. 13, p. 16, 2016. https://doi.org/10.1186/s41239-017-0051-4

[3] M. M. Abbad and F. N. Jaber, "Evaluating e-learning systems: An empirical investigation on students' perception in higher education area," Int. J. Emerg. Technol. Learn., vol. 9, no. 4, pp. 27-34, 2014. https://doi.org/10.3991/ijet.v9i4.3480

[4] N. Emelyanova and E. Voronina, "Introducing a Learning Management System at a Russian University : Students ' and Teachers 'Perceptions," Int. Rev. Res. Open Distance Learn., vol. 15, no. 1, pp. 272-289, 2014. https://doi.org/10.19173/irrodl.v15i1.1701

[5] Y. Zhonggen and Z. Yuexiu, "Blended Learning Over Two Decades," Int. J. Inf. Commun. Technol. Educ., vol. 11, no. 3, pp. 1-19, 2015.

[6] M. Macedo-Rouet, M. Ney, S. Charles, and G. Lallich-Boidin, "Students' performance and satisfaction with Web vs. paper-based practice quizzes and lecture notes," Comput. Educ., vol. 53, no. 2, pp. 375-384, 2009. https://doi.org/10.1016/j.compedu.2009.02.013

[7] J. M. O. Toole and D. J. Absalom, "The Impact of Blended Learning on Student Outcomes : is there room on the horse for two ?," no. September 2013, pp. 37-41, 2010.

[8] C. V. and T. R. W. Banyen, "A Blended Learning Model for Learning Achievement Enhancement of Thai Undergraduate Students," Int. J. Emerg. Technol. Learn., vol. 11, no. 4, pp. 48-55, 2016. https://doi.org/10.3991/ijet.v11i04.5325

[9] H.-J. So and T. A. Brush, "Student perceptions of collaborative learning, social presence and satisfaction in a blended learning environment: Relationships and critical factors," Comput. Educ., vol. 51, no. 1, pp. 318-336, 2008. https://doi.org/10.1016/j.compedu.2007. 05.009

[10] L. O. Seman, R. Hausmann, and E. A. Bezerra, "On the students' perceptions of the knowledge formation when submitted to a Project-Based Learning environment using web applications," Comput. Educ., 2017. https://doi.org/10.1016/j.compedu.2017.10.001

[11] S. R. G. Fernandes, "Preparing Graduates for Professional Practice: Findings from a Case Study of Project-based Learning (PBL)," Procedia - Soc. Behav. Sci., vol. 139, pp. 219 226, 2014. https://doi.org/10.1016/j.sbspro.2014.08.064

[12] M. Radovan, "The Relation Between Distance Students'Motivation, Their Use of Learning Strategies, and Academic Success," Turkish Online J. Educ. Technol., vol. 10, no. 1, pp. 216-222, 2011.

[13] D. J. Nicol and L. A. MacLeod, "Using a shared workspace and wireless laptops to improve collaborative project learning in an engineering design class," Comput. Educ., vol. 44, no. 4, pp. 459-475, 2005. https://doi.org/10.1016/j.compedu.2004.04.008

[14] J. Wakefield, J. K. Frawley, J. Tyler, and L. E. Dyson, "The impact of an iPad-supported annotation and sharing technology on university students' learning," Comput. Educ., vol. 122, pp. 243-259, 2018. https://doi.org/10.1016/j.compedu.2018.03.013

[15] N. Solihati and H. Mulyono, "Designing and evaluating the use of smartphones to facilitate online testing in second-language teacher education (SLTE): An auto-ethnographic study," Int. J. Emerg. Technol. Learn., vol. 13, no. 1, pp. 124-137, 2018. https://doi.org/10.3991/ ijet.v13i01.7683

[16] A. Shoufan, "Estimating the cognitive value of YouTube's educational videos: A learning analytics approach," Comput. Human Behav., 2018. https://doi.org/10.1016/j.chb.2018. $\underline{03.036}$ 
[17] V. Sahasrabudhe and S. Kanungo, "Appropriate media choice for e-learning effectiveness: Role of learning domain and learning style," Comput. Educ., vol. 76, pp. 237-249, 2014. https://doi.org/10.1016/j.compedu.2014.04.006

[18] H. H. Lin, W. C. Yen, and Y. S. Wang, "Investigating the effect of learning method and motivation on learning performance in a business simulation system context: An experimental study," Comput. Educ., vol. 127, pp. 30-40, 2018. https://doi.org/10.1016/j. compedu.2018.08.008

[19] D. Lindenbach, J. K. Seamans, and A. G. Phillips, "Activation of the ventral subiculum reinvigorates behavior after failure to achieve a goal: Implications for dopaminergic modulation of motivational processes," Behav. Brain Res., vol. 356, no. August 2018, pp. 266-270, 2019. https://doi.org/10.1016/j.bbr.2018.09.002

[20] T. Sterling, M. Anderson, and M. Brodowicz, "Operating Systems," High Perform. Comput., pp. 347-362, 2018. https://doi.org/10.1016/b978-0-12-420158-3.00011-3

[21] C. A. R. dos Santos and R. Matias, "Failure patterns in operating systems: An exploratory and observational study," J. Syst. Softw., vol. 137, pp. 512-530, 2018. https://doi.org/10. 1016/j.jss.2017.03.058

[22] S. Abraham, G. Peter Baer, and G. Greg, Operating System Concepts Essentials, Second Edi. United States of America: John Wiley \& Sons, Inc, 2017.

\section{Author}

Wahyudi has a degree Master of Science (Computer Science) from The University Technology Malaysia (UTM). He has participated in Visiting Scholar Doctoral Sandwich Program at Ohio State University (OSU), College of Education and Human Ecology. He has an Edmodo Certified Trainer. He has done many researches in Resources Sharing and Blended Project Based Learning.

Article submitted 2019-07-12. Resubmitted 2019-08-11. Final acceptance 2019-08-12. Final version published as submitted by the authors. 